\title{
The Hidden Scar
}

Every line, every curve, every scar there is a hidden message waiting to be discovered and this is my story, how I found a hidden message.

Ko Te Miringa tōku ingoa. He uri au nō Te Whānau a Apanui, Te Whakatōhea me Ngāpuhi anō hoki.

Do you want to hear something freaky? I'm going to tell you a crazy story of a little scar that changed my life. YES! A fucken scar. Here we go.

Growing up on the coast, your maunga is your backyard, your awa and moana are your local swimming pools; your marae is your playground and your classroom, and your wharekai is your local bank where you go around asking your nannies and koros for some money to go and get some chips and lollies at the shop up the road. This is where my story starts.

Growing up I was a P.P.K (Paru Pā Kid), exposed to a lot of spiritual 'stuff' and experiences. Call it a gift, but being the P.P.K that I was, I would walk away from certain things, and not think anything of it.

One day my cousin Tama and I decided to leave the marae. Oh, before I carry on, according to Nana Muri, my cousin Tama, a.k.a 'Haututu' was the most mischievous little hua of us all. Well, we thought it would be a great idea to go and play hide and seek down at the beach while our parents had haka practice up at the pā. We got bored 
watching them go over and over practicing how to piu properly... like, boring.

So, my cuzzy Tama and I went on a little adventure to the beach. I could sense something was following me. Admittedly, I was SHIT scared. I had never ever felt that scared before.

But cuzzy Tama said, "you're just being a little pussy eah, Miringa." Yip, you know it. That sparked a little fire in my heart to not be a 'little pussy.'

Feeling like I had to prove him wrong, I said, "Fine. You count, and I'll hide, OK?" Off I went to find the best hiding spot ever. Looking around frantically I came across this big tree, bigger than any tree I had ever seen. In the bottom of the tree there was a hollow. Believe it or not, I crawled into that hollow to hide. I thought I had found the best hiding spot in history of hiding spots... until I looked up. Why did I look up? I always ask myself that question. Stunned, shocked and paralysed in that moment, I saw something I had never, ever seen before. Looking down at me was an image, a face, with blue eyes. The skin was white, and the hair was black. It stared right at me, right through me, and moved closer. The voice in my head repeated over and over, "You're not a little pussy, you're not a little pussy, you're not a little pussy..." and my last thought was, "Please find me, Tama," and BOOOOM!! Just like that, I blacked out.

I woke up a couple of hours later with a small wound on my eyelid, and I didn't know how, when, or why I got it. I was back at my nana's whare. Nana Muri was the most beautiful blue eyed, silver haired, light skinned nana in the world, and she had a gift some people would wish for: she made the BEST FRY BREAD EVERRRR, and her steam pudding was HOH! Just being at Nana Muri's house, I automatically felt so safe, warm and happy; it made me forget everything that happened with the... thing. 
"FOUND YOU!!!" Tama burst through the door, I just looked at his dumbass face, and said, "Umm, kare the game's over, " as I rolled my eyes all the way back to Hawaiki.

Tama looked at me and said, "What happened to your eye?" I said I fell over because he would probably think, "Fuck, she's all shit." But facts: I didn't know how I got it. It hurt. Nana Muri said there was going to be a scar there.

We decided to go back to the marae because our parents were probably wondering where we were. As we walked back to the marae, we thought of the most funniest thing ever. Me and Tama didn't like our aunty's new boyfriend - who Tama and I called 'Paranokenoke, ugly city slicker' - who always wore the flashest shoes. We thought we'd hide away the brand new shoes he wore to Te Kaha this week. Ratchet aye? But we just didn't like him one bit. So we took the shoes down to the shop, and tried to sell them to get heaps of money. At the same time, all our aunties and uncles who came to the shop asked, "where's your parents, you little haututus?" or "where would anyone wear those shoes around here?" Tama reckoned "what do we do now?" Just then we hear our Aunty's voice, "Hey you two little huas, do you have your uncle's shoes?" I said, "Nope we don't have any of our uncles shoes. But we do have Paranokenoke's shoes," big as smiles on our faces. We immediately cracked up laughing. She laughed with us and gave us some of Paranokenoke's money. Yeah, buddy! \$10.00 each. In that moment I felt like the richest little kid ever. We were really out there, hustling. And winning! Perks of living on the coast are the life lessons everywhere we go. Even though this has been one of the best weekends ever, it just sucks that something sad always has to happen.

It was time for haututu Tama to go back home to Ōpōtiki, which is only one hour, but if you know the roads a thirty minute ride. Heoi, I hate saying goodbye to Tama because 
we are so awkward. We'd just look at each other and say, "see ya later, you ugly haututu." I didn't know that this would be the last time I would see Tama in my childhood.

\section{0yrs later}

On my 18th birthday I woke up feeling like a new woman because I was now officially one (with a wink and a grin). Feeling like something so heavy had lifted off my shoulders or in this case my eyelid, the scar that I got ten years earlier had disappeared overnight. I really didn't think much of it, and carried on with my day because it's my fucken birthday. I knew that Nana Muri would make me a birthday breakfast. I was about to get extra fat because that shiiiiiit smelt so good, it made my mouth water, I just couldn't wait. Yum.

I walked out into the kitchen, "Hari rā whānau my Te Miringa $\mathrm{O}$ Te Marama. You are old now my haututu moko" Nannie proclaims. "Ngā mihi, my nannie." Honestly I really couldn't ask for anything else. You see, I have my Nanny Muri here with me, massive amounts of kina, creamed paua and her famous fried bread. Well... famous to me anyways. Man we are about to get fat-fat, it's worth every centimetre.

While we were having our kai, Nana Muri looked at me and said, "Moko, the scar on your eyelid has gone." "Yeah Nan, I don't know what happened but I'm happy it's gone because that shit was ugly," I said pointing my eyelid with a creamed paua finger. I noticed the look on her face change, and she looked worried. "My darling, moko" she started, "I need to tell you a story." Confused, I stared at Nan, listening attentively. Her story is about her scar when she was a small child, just like the one I had until last night. At this point I'm very interested in her story.From the banks of the Kererū River, here in Te Kaha, she jumped off the cliff, and hit the bottom, yes, rock bottom. She hit her eye on a sharp rock. What she 
said next had me shitting myself. Nan said, "Moko when I hit the bottom, it was very murky. But I had seen something or someone moving towards me and it came closer, I had never seen anything like it before..." "Hurry up, Nan!" I said in anticipation.

Looking me dead in the eyes, she said, "it was... an image, a person with blue eyes, skin was white as could be, and the hair was completely black, black like the night sky with no moon or stars. It stared right at me and moved closer toward me."

I freaked out. "Nan, what the heck? That's exactly what I saw in the hollow of the tree the day I got my scar!"

"I know moko, but don't be scared, it was our kaitiaki," she assured me. "She just paid you a little visit to see if you were okay, and to mark you."

"Wait, what? Mark me you reckon, Nan."

"Yess Te Miringa you heard me right, she marked you."

"Why did she mark me, Nan?"

Nan tells me I come from a strong line of matakite, and I was marked with the scar to protect me from all the negative wairua. But now that I am a young woman and have matured, I'm more aware, the mark could be removed. I was ready to face it and take on this gift that has been handed down to me from my tippuna.

Later that day, I was getting ready to get fucked up and have a good, legal night, so you know what that meant: makeup, the greatest outfit, some Lion Reds, hit the town in Opo, at 'Slims' the best club ever, where all the locals go, and mannnnn, I was excited. As I got ready there was a knock at the door, and as I opened it, my jaw drops to the ground. "Happy birthday, little pussy!" It was Tama. He looked the same, just had clothes that didn't have rips in them this time and he was a head taller than me now. I wrap my arms around my cuzzy. We have a catch up on everything and how we've been. Amazed, Tama realises that my scar has gone. The last time I had seen him was the day I got it. I wasn't about to tell him what Nana Muri 
had just told me because he was already drunk, and I wasn't about to have his bullshit ruin my day, my birthday.

A legal night goes on, and mannnnn, was it a good night, good vibes going, and I got FREE DRINKS.

Later on, I headed out to get some air. I looked to the sky, at the mārama. Happy birthday to me. But at that moment, I felt like something had just ripped my heart out. In the distance, I saw the kaitiaki. She moved towards me, closer, closer, to right beside me, and whispered, "Te Miringa me hoki tōtika koe ki te kainga, ināianei." Cuzzy Anahera, the little goodie-two-shoes who doesn't drink or do anything fun, sober drove me that night, and I told her I really needed to go home to Nan's. As we were getting back into Te Kaha, I could feel something was following us. I'd felt that before. I looked out to the moana and saw a tohorā. I got so sad. I knew straight away that it was a tohu. Someone had passed away. The glistening of the moonlight shone on the ocean and lead the tohorā just offshore from where we parked, near Nana Muri's house.

I rushed inside, "NAN! Where are you?" I went out to the deck where Nan would usually sit in her chair, and saw the tohora swimming directly off the front of the deck. In the corner of my eye I saw Nana Muri sitting there in her chair, as usual. She looked up at me, "Stop yelling my moko, I know you're ready, be strong, be proud to be you and never be embarrassed of where you come from. Love you my Te Miringa O Te Mārama." Her voice softened to a quiet whisper, peacefully she made her way to Koro. My heart sank so deep inside myself.

I cried out through all my pain to the moana, a maioha, "E ua e te ua taheke ki runga aku pare kawakawa kua riro atu ra." During my call, I saw the tohorā swimming away. But this time, another one swam beside it. Such a beautiful sight. That must've been Koro coming to pick 
up his one and only true love. My Nanny Muri. Haere, haere, haere atu rā.

Over 40 years later

I'm 60 now, I do not have Alzheimer's yet. I can still remember everything vividly. Cuzzy Tama and I will keep our haututu stories for another time. When you see that kaitiaki, tell her I said, "Kiaora kare!" and be careful, because you could be next. 